\title{
La famille dans les Pyrénées, de la coutume au Code Napoléon
}

\author{
Jacques Bourdin
}

\section{(2) OpenEdition \\ 12 Journals}

\section{Édition électronique}

URL : https://journals.openedition.org/ahrf/1571

DOI : 10.4000/ahrf.1571

ISSN : 1952-403X

Éditeur :

Armand Colin, Société des études robespierristes

\section{Édition imprimée}

Date de publication : 1 septembre 2004

Pagination : 239

ISSN : 0003-4436

\section{Référence électronique}

Jacques Bourdin, "La famille dans les Pyrénées, de la coutume au Code Napoléon », Annales

historiques de la Révolution française [En ligne], 337 | juillet-septembre 2004, mis en ligne le 15 février 2006, consulté le 23 avril 2022. URL : http://journals.openedition.org/ahrf/1571 ; DOI : https://doi.org/ 10.4000/ahrf.1571

Ce document a été généré automatiquement le 23 avril 2022.

Tous droits réservés 


\title{
La famille dans les Pyrénées, de la coutume au Code Napoléon
}

\author{
Jacques Bourdin
}

\section{RÉFÉRENCE}

Christine Lacanette-Pommel, La famille dans les Pyrénées, de la coutume au Code Napoléon, Universatim, PyréGraph, 2003, 232 p., ISBN 2-908723-52-2, $35 €$

1 Selon le mythe complaisamment développé par Le Play, les familles des vallées d'Ossau et d'Aspe, dans les Pyrénées, auraient massivement et farouchement résisté aux lois révolutionnaires et au Code civil pour défendre le système coutumier de la «maison » et la coutume locale ou « For de Béarn ».

2 Ne méconnaissant pas l'apport de ses prédécesseurs, de Le Play à Bourdieu, de J. Poumarède à $\mathrm{A}$. Zink et à tous ceux qui sont abondamment cités dans l'introduction, Christine Lacanette-Pommel veut dépasser le cadre purement juridique de l'étude. À cet effet, elle a mis en œuvre un corpus de 5000 actes, provenant des archives notariales (contrats de mariage, testaments, partages, ventes, cessions de droits, quittances, transactions) et judiciaires, lors des conflits familiaux.

3 Le livre se décompose en deux parties. La première décrit les réactions face aux lois révolutionnaires (pp. 21-48), puis au Code civil (pp. 49-101). La seconde montre, au sein de l'assimilation du Code, le maintien de la "maison », sans la coutume, au XIXe siècle (pp. 105-171), la création de droits nouveaux et les changements sociaux intervenus (pp. 173-200). Le tout, fortement argumenté, les exemples significatifs multipliés, les discordances montrées entre les vallées, et entre hautes et basses vallées, les différentes stratégies face à la pérennité de l'oustau prises en compte, les revendications des cadets et des femmes mises en valeur.

4 L'étude mène à des conclusions nuancées. Certes, le mythe d'une résistance farouche aux lois nouvelles a vécu. Face à celles de nivôse an II, puis au Code civil, individus et familles ont eu recours à trois réponses : de la part des aînés, le recours à la fraude, 
pour maintenir leurs avantages (mais la fraude n'a pas été massive); de la part des cadets, l'utilisation des lois nouvelles (surtout celles de la Révolution) pour obtenir le partage de la «maison ». Entre ces deux extrêmes, les familles ont réussi à négocier le maintien de l'héritage, à l'amiable, dans le secret des études notariales. La solution judiciaire, synonyme de division de la "maison", a concerné une centaine de familles dans la première moitié du XIXe siècle. Elle marque l'impact des règles égalitaires en Béarn, la fragilité de la permanence de l'oustau que seule contrebalance la cohésion familiale. 